\title{
Original Article Jungle Honey Enhances Immune Function and
Antitumor Activity
}

\section{Miki Fukuda, ${ }^{1}$ Kengo Kobayashi,, ${ }^{1}$ Yuriko Hirono, ${ }^{1}$ Mayuko Miyagawa, ${ }^{1}$ Takahiro Ishida, ${ }^{1}$ Emenike C. Ejiogu, ${ }^{2}$ Masaharu Sawai, ${ }^{3}$ Kent E. Pinkerton, ${ }^{4}$ and Minoru Takeuchi ${ }^{1}$}

\author{
${ }^{1}$ Department of Biotechnology, Faculty of Engineering, Kyoto Sangyo University, Kyoto, Japan \\ ${ }^{2}$ Origins Japan Co. Ltd, Nagano, Japan \\ ${ }^{3}$ Takara Shuzo Co. Ltd, Kyoto, Motoyama, Kamigamo, Kita-ku, Kyoto 603-8555, Japan \\ ${ }^{4}$ Center for Health and the Environment, University of California Davis, California, USA
}

Correspondence should be addressed to Minoru Takeuchi, mtakex@cc.kyoto-su.ac.jp

Received 16 June 2008; Accepted 17 December 2008

Copyright ( 2011 Miki Fukuda et al. This is an open access article distributed under the Creative Commons Attribution License, which permits unrestricted use, distribution, and reproduction in any medium, provided the original work is properly cited.

\begin{abstract}
Jungle honey $(\mathrm{JH})$ is collected from timber and blossom by wild honey bees that live in the tropical forest of Nigeria. JH is used as a traditional medicine for colds, skin inflammation and burn wounds as well as general health care. However, the effects of JH on immune functions are not clearly known. Therefore, we investigated the effects of $\mathrm{JH}$ on immune functions and antitumor activity in mice. Female C57BL/6 mice were injected with $\mathrm{JH}(1 \mathrm{mg} / \mathrm{mouse} /$ day, seven times intra-peritoneal). After seven injections, peritoneal cells (PC) were obtained. Antitumor activity was assessed by growth of Lewis Lung Carcinoma/2 (LL/2) cells. PC numbers were increased in JH-injected mice compared to control mice. In Dot Plot analysis by FACS, a new cell population appeared in JH-injected mice. The percent of Gr-1 surface antigen and the intensity of Gr-1 antigen expression of PC were increased in JH-injected mice. The new cell population was neutrophils. JH possessed chemotactic activity for neutrophils. Tumor incidence and weight were decreased in JH-injected mice. The ratio of reactive oxygen species (ROS) producing cells was increased in JHinjected mice. The effective component in $\mathrm{JH}$ was fractionized by gel filtration using HPLC and had an approximate molecular weight (MW) of 261. These results suggest that neutrophils induced by JH possess potent antitumor activity mediated by ROS and the effective immune component of JH is substrate of MW 261.
\end{abstract}

\section{Introduction}

Natural products are known to have biological activity, and we have previously investigated the effect of natural products on immune function $[1,2]$. Honey contains various vitamins, minerals and amino acids as well as glucose and fructose and is popular as a natural food [3-6]. There is a wide variety of honey (Manuka honey, Pasture honey, Jelly bush honey and Jungle honey, etc.), and the varieties are due to components of the flower sources. Honey is used not only as natural food but also as traditional medicine for health care, in beauty products and antiinflammatory skin care. One variety, Jungle honey, is collected from timber and blossom by wild honeybees that live in the tropical forest of Nigeria. Jungle honey is used as traditional medicine or preventive medicine to treat colds, skin inflammation and burn wounds as well as for general health care.
It is generally known that honey has antibacterial activity that has been reported to be due to its high osmolarity, acidity and presence of hydrogen peroxide and unidentified substances from floral sources [7-11]. It has been reported that flavonoid and phenol acid show antibacterial activity [12-14]. It was reported in a clinical experiment that when wound infected with gram positive and gram negative bacteria were treated with honey, infection was more quickly eradicated [15-17].

It has been reported that Manuka honey increased IL$1 \beta$, IL- 6 , and TNF- $\alpha$ production from Mono Mac6 cells or human monocytes $[18,19]$, and the active component was $5.8 \mathrm{kDa}$, which increased production of these cytokines via TLR4 [20]. In addition, it was reported that oral intake of honey augmented antibody productions in primary and secondary immune responses against thymus-dependent and thymus-independent antigens [21]. 
Honey may provide the basis for the development of novel therapeutics for patients with wounds. Therefore, the purpose of this study was to investigate the effects of Jungle honey on immune function and antitumor activity in mice.

\section{Methods}

2.1. Preparation of Jungle Honey. Jungle honey $(\mathrm{JH})$ was a gift from Nihon origins Co. Ltd (Nagano, Japan). JH was harvested in the forest areas around the Nsukka area of Enugu state, Nigeria [22]. Generally, the bees were Apis mellifera adonsonii. The main plant species that the bees collected from nectar were Pentaclethra macrophylla, Chrysophyllum albidum and Milicia excela. Briefly, the components of $\mathrm{JH}$ in $100 \mathrm{~g}$ were $900 \mathrm{mg}$ protein, $1400 \mathrm{mg}$ glucon acid, $657 \mathrm{mg}$ amino acid, $213 \mathrm{mg}$ mineral and $3.46 \mathrm{mg}$ vitamin. $\mathrm{JH}$ was dissolved with distilled water, freeze dried and then adjusted to $10 \mathrm{mg} / \mathrm{mL}$ with $\mathrm{PBS}(-)$. JH was steriled by $0.22-\mu \mathrm{m}$ filtration (Millipore, MA, USA) and then stored at $4^{\circ} \mathrm{C}$ before use. The endotoxin unit of $\mathrm{JH}$ was found to be $2.7 \mathrm{EU} / \mathrm{mL}$ using the limulus amebocyte lysate assay kit (Canbrex, MD, USA). The mice did not immunologically respond to this unit of endotoxin.

2.2. Mice. Female C57BL/6 mice were used at 8-10 weeks. Ten mice were used in each group. Mice were obtained from Japan SLC (Shizuoka, Japan). They were housed in transparent plastic cages with stainless wire lids in the animal facility of Kyoto Sangyo University (Kyoto, Japan). They were maintained under standard conditions, with a dark period from $8 \mathrm{pm}$ to $8 \mathrm{am}$, and water and food were provided ad libitum. This study was approved by the committee for animals in Kyoto Sangyo University. Mice were intraperitoneally (i.p.) injected seven times with $\mathrm{JH}$ at a dose of $1 \mathrm{mg} / \mathrm{mouse} /$ day. Control mice received $\mathrm{PBS}(-)\left[\mathrm{Ca}^{2+}, \mathrm{Mg}^{2+}\right.$-free Dulbecco's phosphate buffered saline (Nissui Pharmaceutical, Tokyo, Japan)].

2.3. Analysis of Peritoneal Cells (PC). Peritoneal cells were analyzed using Fluorescence Activated cell Sorter (FACS) Calibur (Becton-Dickinson, CA, USA). After seven injections of $\mathrm{JH}, \mathrm{PC}$ were collected by peritoneal lavage from the mice with cold PBS. PC were pooled into plastic tubes and centrifuged at $185 \mathrm{~g}$ for $10 \mathrm{~min}$. The pelletted cells were resuspended at $1 \times 10^{6}$ cells $/ \mathrm{mL}$ in FACS buffer (PBS containing $100 \mu \mathrm{g} / \mathrm{mL} \mathrm{CaCl}_{2} / \mathrm{MgCl}_{2}, 0.01 \%$ sodium azide and $1 \%$ FCS). The newly appearing cell population found via Dot Plot analysis after JH exposure was sorted by FACS. The sorted cell population was suspended at $5 \times 10^{5}$ cells $/ \mathrm{mL}$ in $\mathrm{R}(+)$ (RPMI1640 containing 10\% fetal calf serum, $100 \mathrm{U} / \mathrm{mL}$ penicillin, $100 \mu \mathrm{g} / \mathrm{mL}$ streptomycin). The cell suspension $\left(200 \mu \mathrm{L}\right.$ of $5 \times 10^{5}$ cells $\left./ \mathrm{mL}\right)$ was put on a slide glass using Cyto Spin and centrifuged at $185 \mathrm{~g}$ for $5 \mathrm{~min}$. After the slide glasses were dried in a dryer, the cells were fixed for $3 \mathrm{~min}$ by methanol, followed by Giemsa stain. Giemsa-stained samples were observed using a light microscope.
2.4. Chemotaxis Assay Using EZ-TAXIScan. Neutrophils were obtained from guinea pig peripheral blood. Blood was diluted twice with PBS. To precipitate red blood cells, peripheral blood was added in equal parts to $3.5 \%$ Dextran in saline and incubated at room temperature for $30 \mathrm{~min}$. The leucocyte-rich supernatant was centrifuged at $400 \mathrm{~g}$ for $30 \mathrm{~min}$ on a Ficoll-Paque Plus (GE Healthcare, Tokyo, Japan) density gradient. The pellet was hemolyzed by hypotonic lysis. Fractionated neutrophils were centrifuged at $185 \mathrm{~g}$ for $10 \mathrm{~min}$ and resuspended at $2 \times 10^{6}$ cells $/ \mathrm{mL}$ in $\mathrm{R}^{\prime}(+)$ (RPMI1640 containing $0.1 \%$ bovine serum albumin, HEPES). A chemotaxis assay for neutrophils was evaluated with EZ-TAXIScan. Time-lapse images of neutrophils during chemotaxis were obtained using EZ-TAXIScan equipped with a six channel chamber (GE Healthcare). This chamber consists of an etched silicon substrate and a flat glass plate, both of which form two compartments with a $4-\mu \mathrm{m}$ deep microchannel. Neutrophils ( $1 \mu \mathrm{L}$ of $2 \times 10^{6}$ cells $\left./ \mathrm{mL}\right)$ were put into a hole with which the device is held together with a stainless holder, and $1 \mu \mathrm{L}$ of $10^{-6} \mathrm{M} N$-formylmethionyl-leucyl-phenylalanine (fMLP) or $1 \mathrm{mg} / \mathrm{mL} \mathrm{JH}$ was put into a contra-hole. The holder assembly was filled with $\mathrm{R}^{\prime}(+)$ and incubated for $30 \mathrm{~min}$ at $37^{\circ} \mathrm{C}$. A charge-coupled device (CCD) camera was used to record the migration of neutrophils toward the high concentration of each sample. Cells in images were analyzed by TAXIScan Analyzer 2.

2.5. Antitumor Activity. Lewis Lung Carcinoma/2 (LL/2) cells were used as tumor cells. LL/2 cells were maintained in a 10-cm dish (BD Falcon, CA, USA) at 2- to 3-day intervals using $\operatorname{MEM}(+)$ [D-MEM (Nacalai tesque, Kyoto, Japan) containing $10 \%$ fetal calf serum, $100 \mathrm{U} / \mathrm{mL}$ penicillin and $100 \mu \mathrm{g} / \mathrm{mL}$ streptomycin]. After 2-3 days, LL/2 were obtained with trypsin-EDTA $(0.25 \%$ trypsin:0.02\% EDTA $=1: 1$, Nacalai tesque) and washed with $\operatorname{MEM}(-)(\mathrm{D}-\mathrm{MEM}$ containing $100 \mathrm{U} / \mathrm{mL}$ penicillin and $100 \mu \mathrm{g} / \mathrm{mL}$ streptomycin). Hemocytometer and trypan blue dye exclusion testing were used to determine LL/2 total number and viability. Mice injected with JH or PBS $(-)$ were inoculated intraperitoneally with $\mathrm{LL} / 2\left(4 \times 10^{5}\right.$ cells $\left./ 0.2 \mathrm{~mL} / \mathrm{mouse}\right)$. After 4 weeks, antitumor activity was evaluated by tumor incidence and weight. Tumor tissues were fixed in 10\% neutral buffered formalin fixative and paraffin embedded. Sections $(4 \mu \mathrm{m})$ were stained with $\mathrm{H} \& \mathrm{E}$.

2.6. Production of Reactive Oxygen Species. PC $(1 \times$ $10^{5}$ cells $/ 100 \mu \mathrm{L}$ ) were incubated with Hydroethidine (HE, Polysciences, PA, USA, final concentration $10 \mu \mathrm{M})$ or $2^{\prime}, 7^{\prime}$ Dichlorofluorescin diacetate (DCFH-DA, Sigma, MO, USA, final concentration $20 \mathrm{mM}$ ). After a shaking incubation at $37^{\circ} \mathrm{C}$ for $30 \mathrm{~min}$, the cells were washed twice and resuspended in $200 \mu \mathrm{L}$ of PBS(+) (Dulbecco's phosphate buffered saline) and then analyzed using FACS.

2.7. Fractionation of Jungle Honey. JH (100 mg/mL) was fractionized from Fr. 1 to Fr. 5 by gel filtration using a Shodex OHpak SB-802 HQ column and HPLC (LC-20AD, RID-10A, SPD-20A, CB-20A, Simazu, Japan). Elution was 
carried out with $\mathrm{PBS}(-)$ at a flow rate of $1 \mathrm{~mL} / \mathrm{min}$ for $30 \mathrm{~min}$. Standards curves were traced using polyethylene glycols, which had MW of 3930, 1020, and 106 (Polymer Laboratories, Germany), and LCsolution GPC (Shimau), under the same conditions in HPLC. The MW of JH was estimated using the polyethylene glycol standard curves. Each fraction of $\mathrm{JH}$ was freeze dried and then adjusted to a concentration of $10 \mathrm{mg} / \mathrm{mL}$ with $\mathrm{PBS}(-)$.

2.8. Expression of $I L-1 \beta m R N A$. Aliquots of obtained PC $\left(1 \times 10^{5}\right.$ cells $/ 100 \mu \mathrm{L} /$ well $)$ were cultured with or without $\mathrm{JH}$ fractions (final concentration $500 \mu \mathrm{g} / \mathrm{mL}$ ) in 96-well flat bottom culture plates (Becton-Dickinson, MA, USA) at $37^{\circ} \mathrm{C}$ for $24 \mathrm{~h}$ in $5 \% \mathrm{CO}_{2}$. After $24 \mathrm{~h}$, total RNA was isolated by acid guanidinium thiocyanate-phenol-chloroform assay. Total RNA was transcribed to cDNA with MLV reverse transcriptase (Invitrogen, CA, USA). Oligonucleotide primers were used from published cDNA sequences of IL$1 \beta$ (250 bp) and $\beta$-actin (268 bp) (house-keeping gene). PCR was performed for 30 cycles using the following primer pairs: $\beta$-actin sense ( $5^{\prime}$-GCATTGTTACCAACTGGGAC- $\left.3^{\prime}\right)$ and $\beta$-actin antisense $\left(5^{\prime}\right.$-TCTCCGGAGTCCATCACAAT$\left.3^{\prime}\right)$; IL- $1 \beta$ sense $\left(5^{\prime}\right.$-AGCTACCTGTGTCTTTCCCG- $\left.3^{\prime}\right)$ and IL- $1 \beta$ antisense ( $5^{\prime}$-GTCGTTGCTTGGTTCTCCTT- $\left.3^{\prime}\right)$. The amplification profile consisted of denaturation at $94^{\circ} \mathrm{C}$ for $30 \mathrm{~s}$, primer annealing at $56^{\circ} \mathrm{C}$ for $30 \mathrm{~s}$ and extension at $72^{\circ} \mathrm{C}$ for $30 \mathrm{~s}$. PCR products were visualized using ethidium bromide after $8 \%$ polyacrylamide gel electrophoresis. Data on the expression in IL-1 $\beta$ mRNA were quantified by Scion image.

2.9. Statistical Analysis. All values are expressed as mean \pm $\mathrm{SE}$. Comparisons between control and $\mathrm{JH}$-injected mice were made with the Student's $t$-test. Any $P$-values $<.05$ were considered statistically significant.

\section{Results}

3.1. Increases of the Number of PC by Jungle Honey. The number of PC was significantly $(P<.001)$ increased in $\mathrm{JH}$ injected mice $\left(5.13 \pm 0.28 \times 10^{6}\right.$ cells/mouse $)$ compared to control mice $\left(1.17 \pm 0.11 \times 10^{6}\right.$ cells/mouse $)$.

3.2. Induction of New Cell Populations of PC by Jungle Honey. New cell populations in $\mathrm{JH}$-injected mice were found at FSC 120-400, SSC 200-800 by Dot Plot analysis of FACS (Figure 1(b)) compared to control mice (Figure 1(a)). An isolated, new cell population was found, as is shown in Figure 1(c) and the isolated cells were found to be neutrophils (Figure $1(\mathrm{~d})$ ) by Giemsa stain. The new cell population in $\mathrm{JH}$-injected mice was observed by a light microscope and was identified as neutrophils by their morphology (Figure 1(d)).

3.3. Enhancement of Chemotaxis for Neutrophil by Jungle Honey. Forty neutrophils migrated in $30 \mathrm{~min}$ in the $\mathrm{JH}-$ treated group compared to 13 neutrophils in the nontreated group (Figure $2(\mathrm{a})-\mathrm{i}, \mathrm{ii}$ ). The velocity of the migrating neutrophils was $0.17 \pm 0.01 \mu \mathrm{m} / \mathrm{s}$ in the $\mathrm{JH}$-treated group and $0.04 \pm 0.01 \mu \mathrm{m} / \mathrm{s}$ in the non-treated group (Figure 2(b)). The radian of neutrophils was $0.39 \pm 0.04 \mathrm{rad}$ in $\mathrm{JH}-$ treated group and $0.09 \pm 0.03 \mathrm{rad}$ in the non-treated group (Figure $2(\mathrm{~b}))$. JH resulted in significantly $(P<.001)$ increased numbers, velocity, and radiation of migrated cells. Therefore, JH showed chemotactic activity for neutrophils.

3.4. Inhibition of LL/2 Tumor Growth by Jungle Honey. The incidence of LL/2 tumors was $20 \%$ in JH-injected mice and $100 \%$ in control mice (Figure $3(\mathrm{a})$ ). The mean tumor weight was $0.02 \pm 0.02 \mathrm{~g}$ in $\mathrm{JH}$-injected mice and $2.57 \pm$ $1.05 \mathrm{~g}$ in control mice (Figure 3(b)). These results reveal that $\mathrm{JH}$ inhibited tumor incidence and growth (Figure 4). In histological findings of control tumor tissue, necrotic areas were recognized (Figure 4(a)-i, iii), but there were few infiltrations of neutrophils (Figure 4(a)-ii, iv). In $\mathrm{JH}$ injectedtumor tissue, massive necrotic areas (Figure 4(b)-v) and infiltration by many neutrophils were observed (Figure 4(b)vi). Hemorrhagic necrotic areas and a disassociation between tumor cells were found (Figure 4(b)-vii, viii).

3.5. Increases of ROS Production in PC by Jungle Honey. The ratio of control was 1.0. The ratio of $\mathrm{O}_{2}^{-}$was 1.16 and the ratio of $\mathrm{H}_{2} \mathrm{O}_{2}$ was 1.13 in the $\mathrm{JH}$ treated group. The ratio of $\mathrm{O}_{2}^{-}$or $\mathrm{H}_{2} \mathrm{O}_{2}$ producing cells were significantly $(P<.001)$ increased in $\mathrm{JH}$-injected mice compared with control mice (Figure 5). Therefore, Reactive Oxygen Species (ROS) may be associated with antitumor activity.

3.6. Enhancement of $I L-1 \beta m R N A$ Expression in PC by Jungle Honey Fractions. IL- $1 \beta$ mRNA expressions by $\mathrm{JH}$ and each fraction from Fr. 1 to Fr. 5 were $0.94 \pm 0.06,0.67 \pm 0.12,1.11$ $\pm 0.13,0.42 \pm 0.05,0.58 \pm 0.04$ and $0.64 \pm 0.05$, respectively (Figure 6(a)). IL-1 $\beta$ mRNA expressions were significantly $(P$ $<.001$ ) increased by JH or Fr. 2 (Figure 6(b)).

\section{Discussion}

Jungle honey $(\mathrm{JH})$ is collected from timber and blossom by wild honeybees that live in the tropical forest of Nigeria, where $\mathrm{JH}$ is used as traditional or preventive medicine for colds, skin inflammation and burn wounds as well as general health care. Therefore, we expected that $\mathrm{JH}$ would have potential biological, especially immune, activity. Until now, the effect of $\mathrm{JH}$ on immunomodulatory activity has been relatively unknown. Therefore, we investigated the effects of $\mathrm{JH}$ on immune function and antitumor activity in mice.

We found that the number of peritoneal cells (PC) was increased $\sim 4$-fold in $\mathrm{JH}$-injected mice compared with control mice. This result suggests that $\mathrm{JH}$ induces cell migration. Although the effects of other types of honey on PC numbers are not yet reported, mice treated with other natural products (i.e., hydroalcoholic extract from Chenopodium ambrosioides or aqueous extract from Orbignya phalerata Mart) have been shown to have increased PC as well $[23,24]$.

To characterize the new cell population found after $\mathrm{JH}$ treatment, we investigated surface antigens by FACS. In Dot Plot analysis, a new cell population appeared in the region 


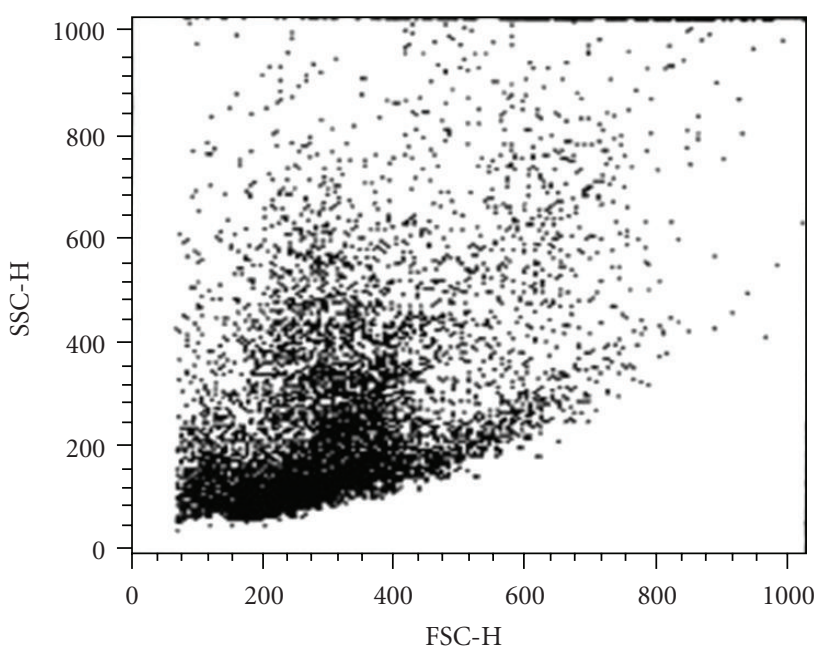

(a) Control

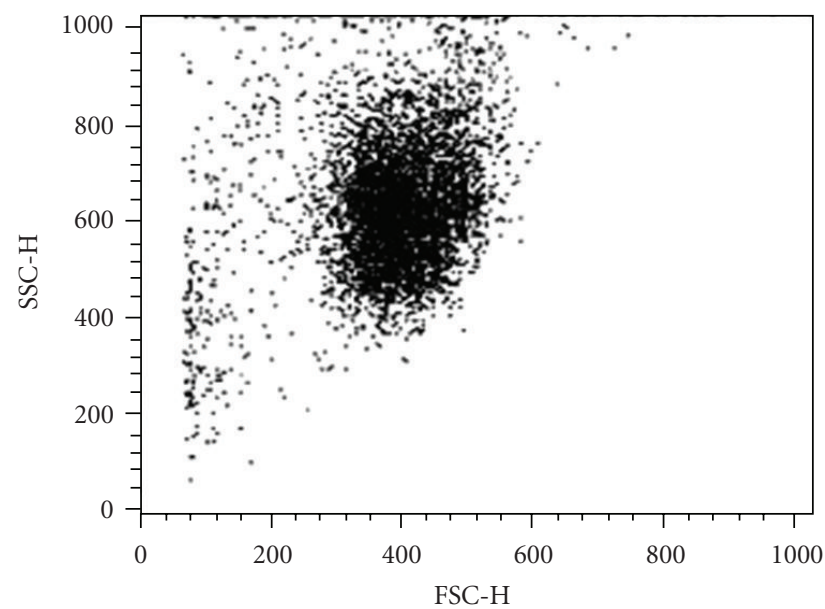

(c) Isolated cell population

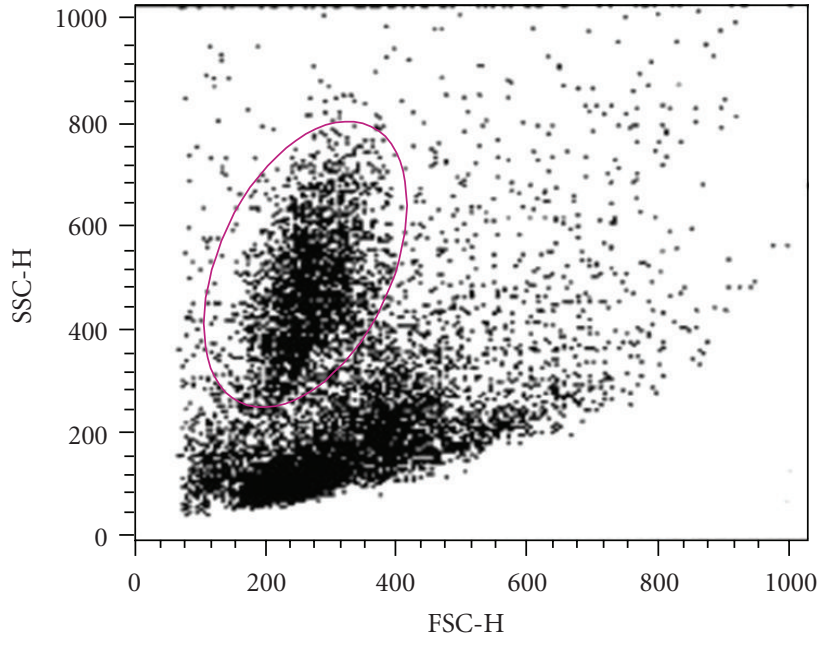

(b) Jungle honey

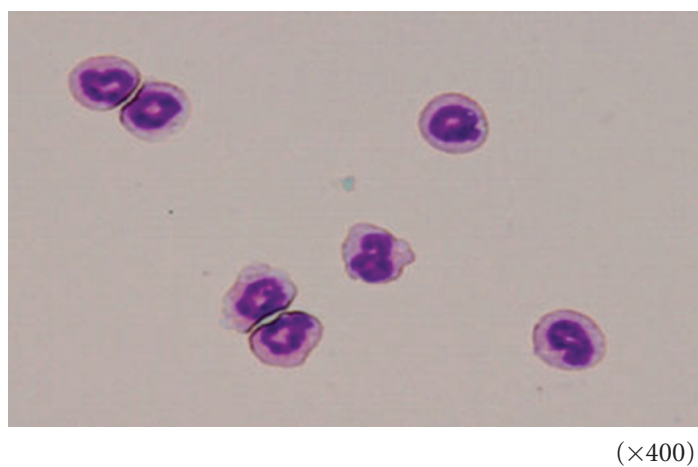

(d) Isolated cell population

Figure 1: Induction of new cell populations of PC by Jungle honey. (a) Control. (b) Jungle honey. (c) Isolated cell population. (d) Isolated cell population.

of FSC $120-400$ and SSC $200-800$ in JH-injected mice. The percent of Gr-1 surface antigen and the intensity of Gr-1 antigen expression of $\mathrm{PC}$ were increased in $\mathrm{JH}$-injected mice (data not shown). Moreover, the new cell population was found to be neutrophils based on morphology. Although the effects of honey on Dot Plot and cell surface antigen of PC were not reported, it was shown that the number of neutrophils was increased in treated mice with propolis [25]. This result agrees with our present report.

Our results showed that $\mathrm{JH}$ may have chemotactic activity for neutrophils. Therefore, we investigated the chemotactic activity of $\mathrm{JH}$ for neutrophils. The velocity and direction of migration were increased by $\mathrm{JH}$ compared with the control treatment. These results suggest that $\mathrm{JH}$ possesses chemotactic activity for neutrophils. Although there are no reports concerning chemotactic activity of honey, polysaccharide from Ganoderma lucidum have chemotactic activity for neutrophils in the Boyden chamber assay [26].
Because it was demonstrated that the number of PC and migration of neutrophils were increased by $\mathrm{JH}$, we investigated antitumor activity by immune cells. LL/2 tumor cells were used as syngeneic tumor cells, which have lowtumor antigen and inhibit the immune system as well as human cancer [27]. The incidence and the mean weight of $\mathrm{LL} / 2$ tumors were decreased in $\mathrm{JH}$-injected mice compared to control mice. These results suggest that $\mathrm{JH}$ has a preventive effect on tumor growth. Tumor weight was found decreased by royal jelly, propolis or polyphenol in propolis [28-30]. The tumor tissue was infiltrated by many neutrophils at massive necrotic areas in $\mathrm{JH}$-injected mice. Therefore, it was suggested that the neutrophils were involved with inhibition of tumor growth.

To investigate the mechanism of antitumor activity by $\mathrm{JH}$, we examined ROS, a well-known antitumor factor. The ratio of ROS produced by cells was increased in $\mathrm{JH}$ injected mice. Although the effect of honey on cellular 


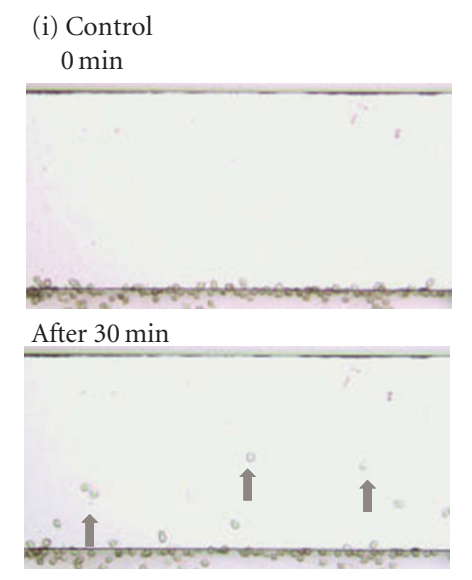

(ii) Jungle honey

$0 \mathrm{~min}$

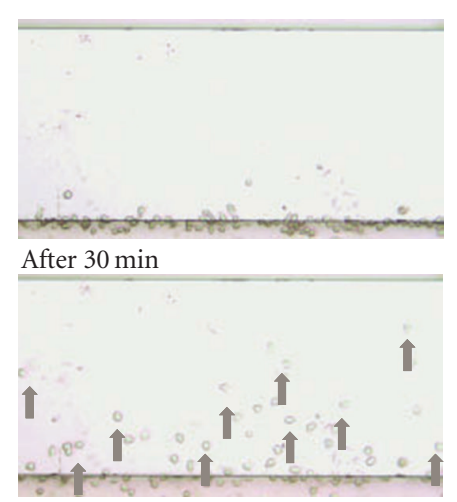

(a) Image of neutrophil chemotaxis

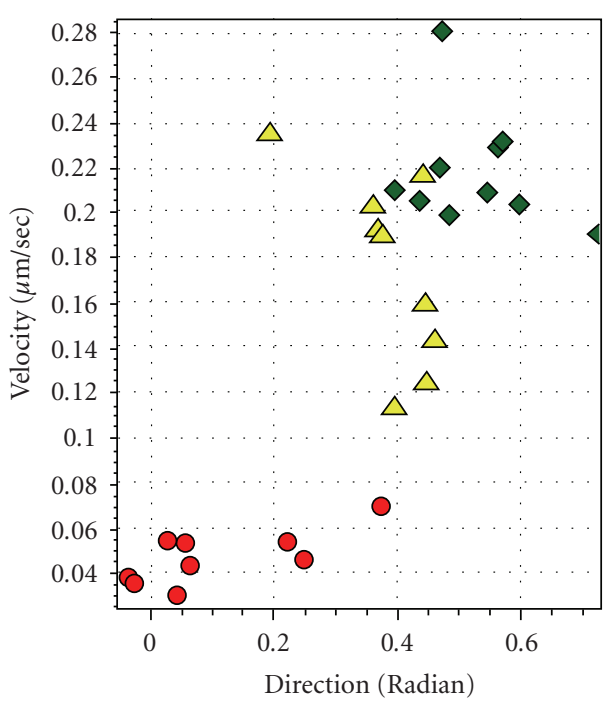

(b) Dot plots of velocity and direction of neutrophils

FIGURE 2: Enhancement of chemotactic activity for neutrophils by Jungle honey. (a) Image of neutrophil chemotaxis. (b) Dot plots of velocity and direction of neutrophils. Up arrow: Migrated cells, filled circle: control, filled diamond: fMLP $\left(10^{-6} \mathrm{M}\right)$, filled triangle: $\mathrm{JH}(1 \mathrm{mg} / \mathrm{mL})$.

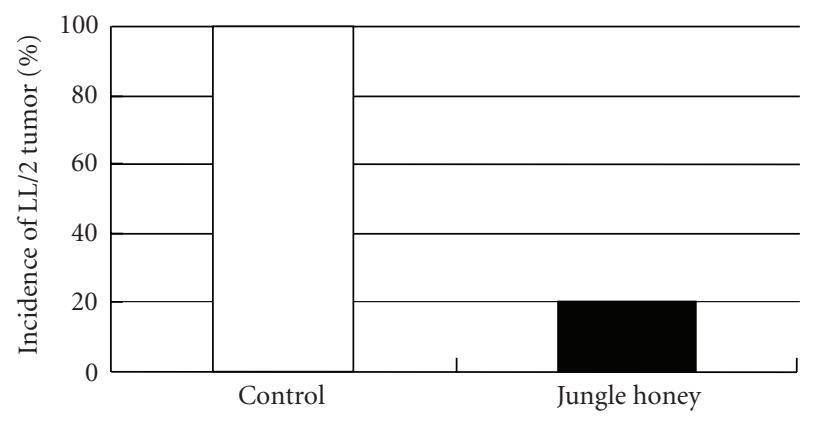

(a) Incidence of LL/2 tumor

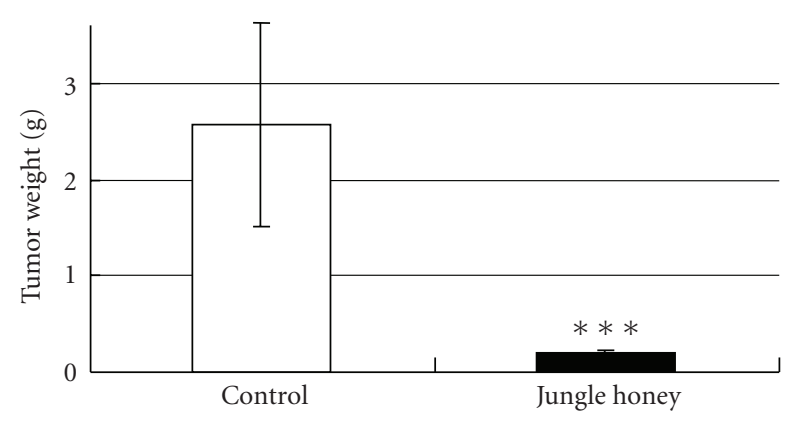

(b) Tumor weight

FIgURE 3: Inhibition of the incidence of LL/2 tumor (a) Tumor weight (a) by Jungle honey.

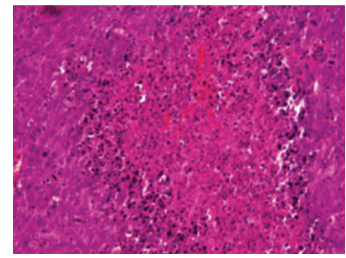

(i) $(\mathrm{x} 200)$

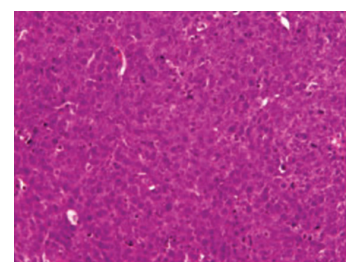

(iii) $(\mathrm{x} 200)$

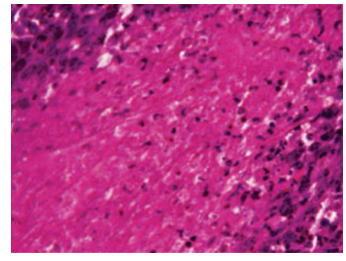

(ii) $(\mathrm{x} 400)$

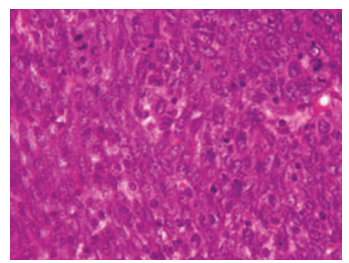

(iv) $(\mathrm{x} 400)$

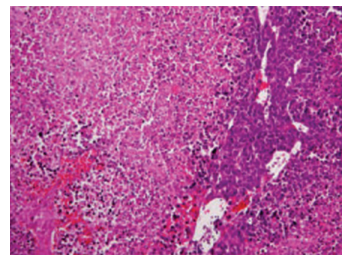

(v) $(\mathrm{x} 100)$

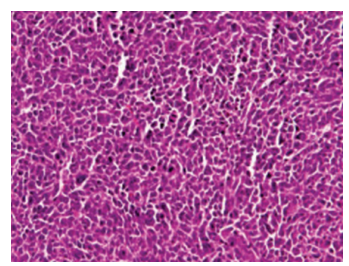

(vii) (x200)

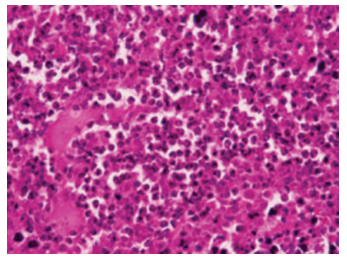

(vi) (x400)

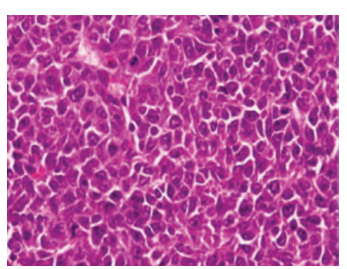

(viii) (x400)
H.E. Stain

(b) Jungle honey

FIGURe 4: Histological findings of LL/2 tumor by Jungle honey. (a) Control. (b) Jungle honey. 


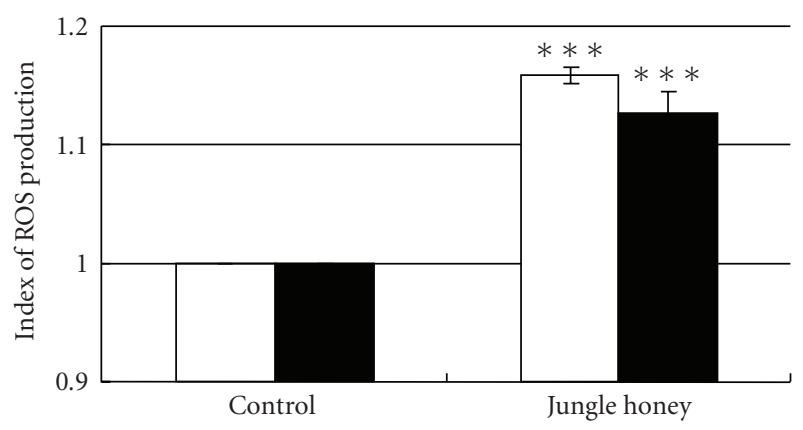

FIGURe 5: Increases of ROS production in PC by Jungle honey. Open square: $\mathrm{O}_{2}^{-}$, filled square: $\mathrm{H}_{2} \mathrm{O}_{2}$.

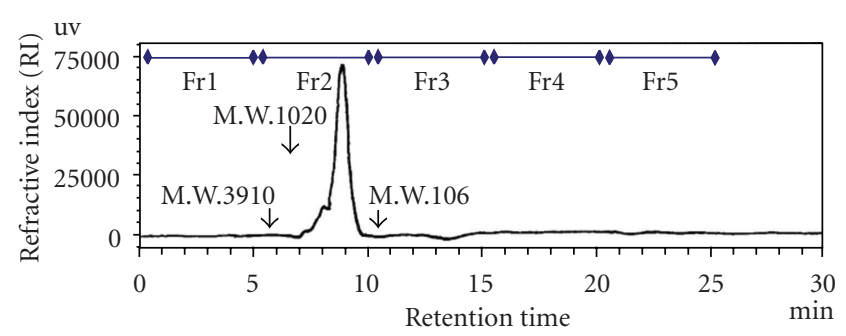

(a) Fraction by gel filtration

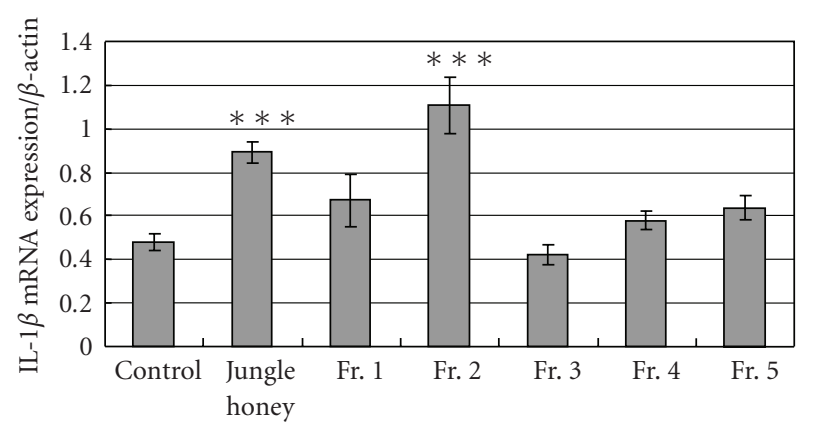

(b) IL-1 $\beta$ mRNA expression

FIgURE 6: Enhancement of IL- $1 \beta$ mRNA expression in PC by Jungle honey fractions. (a) Fraction by gel filtration. (b) IL- $1 \beta$ mRNA expression.

ROS production has hereto been unreported, one study reported that $\mathrm{H}_{2} \mathrm{O}_{2}$ production was increased in PC treated with extracts of G. lucidum or P. cornucopiae [31]. This result agrees with our present study. It was reported that ROS produced by activated neutrophils has tumor cytotoxic properties as well as preventive action against infection [3235]. Since infiltration of many neutrophils was observed at necrotic areas in $\mathrm{JH}$ injected-tumor tissue, there is a possibility that antitumor activity by $\mathrm{JH}$ is due to production of ROS by infiltrated neutrophils into tumor tissue.

JH was fractionized from Fr. 1 to Fr. 5 by gel filtration using HPLC to identify the effective component in $\mathrm{JH}$, and IL-1 $\beta$ mRNA expressions in PC were assayed using each fraction. IL- $1 \beta$ augments immune response, functions and migration capability of neutrophils. JH and Fr. 2 augmented the expression of IL- $1 \beta$ mRNA in PC. Therefore, the effective component was Fr. 2 in $\mathrm{JH}$, and the effective component in
Fr. 2 was estimated to have a MW of 261. In contrast, it was reported that the effective component of honey or royal jelly was $55 \mathrm{kDa}$ (Apalbumin-1), and the effective component of Manuka honey was $5.8 \mathrm{kDa}$; these two components also were found to increase TNF- $\alpha$ production $[19,36-38]$. Therefore, the active component of honey or royal jelly and Manuka honey differs from the active component of $\mathrm{JH}$.

Our results suggested that $\mathrm{JH}$-induced neutrophils to the peritoneal cavity, and the neutrophils were activated by IL$1 \beta$, which was produced by $\mathrm{JH}$ stimulation. Then ROS from activated neutrophils was associated with antitumor activity. In addition, the effective component in $\mathrm{JH}$ was found to have a MW of 261 .

\section{Funding}

Grant-in-Aid for Scientific Research (C) in Japan Society for the Promotion of Science (Grant no. 20500606).

\section{Acknowledgment}

The authors appreciate Dr Suzette Smiley-Jewell for her efforts to provide technical assistance and suggestions in the preparation of this manuscript.

\section{References}

[1] M. Takeuchi, M. Kimoto, I. Suzuki, and K. Nomoto, "Effect of BCG sensitization on the generation of tumor specific killer T cells," Japanese Journal of Cancer, vol. 10, pp. 1980-1986, 1993.

[2] A. Nakajima, T. Ishida, M. Koga, T. Takeuchi, O. Mazda, and M. Takeuchi, "Effect of hot water extract from Agaricus blazei Murill on antibody-producing cells in mice," International Immunopharmacology, vol. 2, no. 8, pp. 1205-1211, 2002.

[3] P. Y. Qiu, H. B. Ding, Y. K. Tang, and R. J. Xu, "Determination of chemical composition of commercial honey by near-infrared spectroscopy," Journal of Agricultural and Food Chemistry, vol. 47, no. 7, pp. 2760-2765, 1999.

[4] R. J. Weston and L. K. Brocklebank, "The oligosaccharide composition of some New Zealand honeys," Food Chemistry, vol. 64, no. 1, pp. 33-37, 1999.

[5] E. E. Stinson, M. H. Subers, J. Petty, and J. W. White Jr., "The composition of honey. V. Separation and identification of the organic acids," Archives of Biochemistry and Biophysics, vol. 89, no. 1, pp. 6-12, 1960.

[6] V. Bankova, "Recent trends and important developments in propolis research," Evidence-Based Complementary and Alternative Medicine, vol. 2, no. 1, pp. 29-32, 2005.

[7] P. E. Lusby, A. Coombes, and J. M. Wilkinson, "Honey: a potent agent for wound healing?" Journal of Wound, Ostomy, and Continence Nursing, vol. 29, no. 6, pp. 295-300, 2002.

[8] R. A. Cooper, P. C. Molan, and K. G. Harding, "Antibacterial activity of honey against strains of Staphylococcus aureus from infected wounds," Journal of the Royal Society of Medicine, vol. 92, no. 6, pp. 283-285, 1999.

[9] S. Bogdanov, "Nature and origin of the antibacterial substances in honey," Lebensmittel-Wissenschaft + [i.e. und] Technologie, vol. 30, pp. 748-753, 1999.

[10] K. L. Allen, P. C. Molan, and G. M. Reid, "A survey of the antibacterial activity of some New Zealand honeys," Journal 
of Pharmacy and Pharmacology, vol. 43, no. 12, pp. 817-822, 1991.

[11] N. A. L. Somal, K. E. Coley, P. C. Molan, and B. M. Hancock, "Susceptibility of Helicobacter pylori to the antibacterial activity of manuka honey," Journal of the Royal Society of Medicine, vol. 87, no. 1, pp. 9-12, 1994.

[12] H. A. L. Wahdan, "Causes of the antimicrobial activity of honey," Infection, vol. 26, no. 1, pp. 26-31, 1998.

[13] T. P. T. Cushnie and A. J. Lamb, "Antimicrobial activity of flavonoids," International Journal of Antimicrobial Agents, vol. 26, no. 5, pp. 343-356, 2005.

[14] A. Daugsch, C. S. Moraes, P. Fort, and K. P. Yong, "Brazilian red propolis_chemical composition and botanical origin," Evidence-Based Complementary and Alternative Medicine. In press.

[15] N. S. Al-Waili and K. Y. Saloom, "Effects of topical honey on post-operative wound infections due to gram positive and gram negative bacteria following caesarean section and hysterectomies," European Journal of Medical Research, vol. 4, pp. 126-130, 1999.

[16] J. M. Albietz and L. M. Lenton, "Effect of antibacterial honey on the ocular flora in tear dediciency and meibomian gland disease," Cornea, vol. 25, pp. 1012-1019, 2006.

[17] A. Simon, K. Traynor, K. Santos, G. Blaser, U. Bode, and P. Molan, "Medical honey for wound care- Still the 'Latest Resort'?" Evidence-Based Complementary and Alternative Medicine. In press.

[18] A. J. Tonks, R. A. Cooper, K. P. Jones, S. Blair, J. Parton, and A. Tonks, "Honey stimulates inflammatory cytokine production from monocytes," Cytokine, vol. 21, no. 5, pp. 242-247, 2003.

[19] A. Tonks, R. A. Cooper, A. J. Price, P. C. Molan, and K. P. Jones, "Stimulation of TNF- $\alpha$ release in monocytes by honey," Cytokine, vol. 14, no. 4, pp. 240-242, 2001.

[20] A. J. Tonks, E. Dudley, N. G. Porter et al., "A 5.8-kDa component of manuka honey stimulates immune cells via TLR4," Journal of Leukocyte Biology, vol. 82, no. 5, pp. 11471155, 2007.

[21] N. S. Al-Waili and A. Haq, "Effect of honey on antibody production against thymus-dependent and thymus-independent antigens in primary and secondary immune responses," Journal of Medicinal Food, vol. 7, pp. 491-494, 2004.

[22] C. U. Okoye and A. E. Agwu, "Factors affecting agroforestry sustainability in bee endemic parts of Southeastern Nigeria," Journal of Sustainable Forestry, vol. 26, no. 2, pp. 132-154, 2008.

[23] G. V. Cruz, P.V. Pereira, F. J. Patricio et al., "Increase of cellular recruitment, phagocytosis ability and nitric oxide production induced by hydroalcoholic extract from Chenopodium ambrosioides leaves," The Journal of Ethnopharmacology, vol. 111, pp. 148-154, 2007.

[24] F. R. F. Nascimento, E. S. B. Barroqueiro, A. P. S. Azevedo et al., "Macrophage activation induced by Orbignya phalerata Mart," The Journal of Ethnopharmacology, vol. 103, no. 1, pp. 53-58, 2006.

[25] N. Orsolic and I. Basic, "Water-soluble derivative of propolis and its polyphenolic compounds enhance tumoricidal activity of macrophages," The Journal of Ethnopharmacology, vol. 102, no. 1, pp. 37-45, 2005.

[26] M.-J. Hsu, S.-S. Lee, S.T. Lee, and W.-W. Lin, "Signaling mechanisms of enhanced neutrophil phagocytosis and chemotaxis by the polysaccharide purified from Ganoderma lucidum," British Journal of Pharmacology, vol. 139, pp. 289-298, 2003.
[27] M. Shinya, O. Mazda, C. Tsuchihara, H. Hirai, J. Imanishi, and M. Takeuchi, "Interleukin-2 abolishes myeloid cell accumulation induced by Lewis lung carcinoma," Journal of Interferon \& Cytokine Research, vol. 23, pp. 631-638, 2003.

[28] T. Tamura, A. Fujii, and N. Kuboyama, "Antitumor effects of royal jell (RJ)," Nippon Yakurigaku Zasshi, vol. 89, pp. 73-80, 1987.

[29] N. Orsolic, L. Sver, S. Terzic, Z. Tadic, and I. Basic, "Inhibitory effect of water-soluble derivative of propolis and its polyphenolic compounds on tumor growth and metastasizing ability: a possible mode of antitumor action," Nutrition and Cancer, vol. 47, pp. 156-163, 2003.

[30] C. Chia-Nan, W. Meng-Shih, W. Chia-Li, and L. JenKun, "Comparison of radical scavenging activity, cytotoxic effects and apoptosis induction in human melanoma cells by Taiwanese propolis from different sources," Evidence-Based Complementary and Alternative Medicine, vol. 1, pp. 175-185, 2004.

[31] M. Shamtsyan, V. Konusova, Y. Maksimova et al., "Immunomodulating and anti-tumor action of extracts of several mushrooms," Journal of Biotechnology, vol. 113, no. 1-3, pp. 77-83, 2004.

[32] S. Matsugo, M. Sasai, H. Shinmori, F. Yasui, M. Takeuchi, and T. Takeuchi, "Generation of a novel fluorescent product, monochlorofluorescein from dichlorofluorescin by photoirradiationdagger," Free Radical Research, vol. 40, no. 9, pp. 959-965, 2006.

[33] R. A. Clark and S. Szot, "The myeloperoxidase-hydrogen peroxide-halide system as effector of neutrophil-mediated tumor cell cytotoxicity," Journal of Immunology, vol. 126, no. 4, pp. 1295-1301, 1981.

[34] R. A. Clark and S. J. Klebanoff, "Neutrophil mediated tumor cell cytotoxicity: role of the peroxidase system," Journal of Experimental Medicine, vol. 141, no. 6, pp. 1442-1447, 1975.

[35] F. Dallegri, G. Frumento, and F. Patrone, "Mechanisms of tumour cell destruction by PMA-activated human neutrophils," Immunology, vol. 48, no. 2, pp. 273-279, 1983.

[36] S. Nagai, N. Satake, T. Mio, M. Takeuchi, K. Kusume, K. Nishimura et al., "The role of neutrophils in inflammatory lung diseases," Respiratory Research, vol. 11, pp. 150-155, 1992.

[37] J. Majtan, E. Kovacova, K. Bilikova, and J. Simuth, "The immunostimulatory effect of the recombinant apalbumin 1major honeybee royal jelly protein-on TNF $\alpha$ release," International Immunopharmacology, vol. 6, pp. 269-278, 2006.

[38] J. Simuth, K. Bilikova, E. Kovacova, Z. Kuzmova, and W. Schroder, "Immunochemical approach to detection of adulteration in honey: physiologically active royal jelly protein stimulating TNF-alpha release is a regular component of honey," Journal of Agricultural and Food Chemistry, vol. 52, pp. 2154-2158, 2004. 


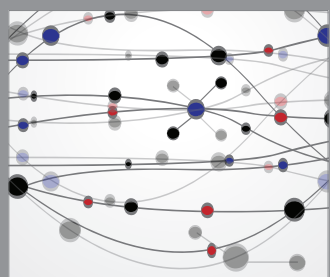

The Scientific World Journal
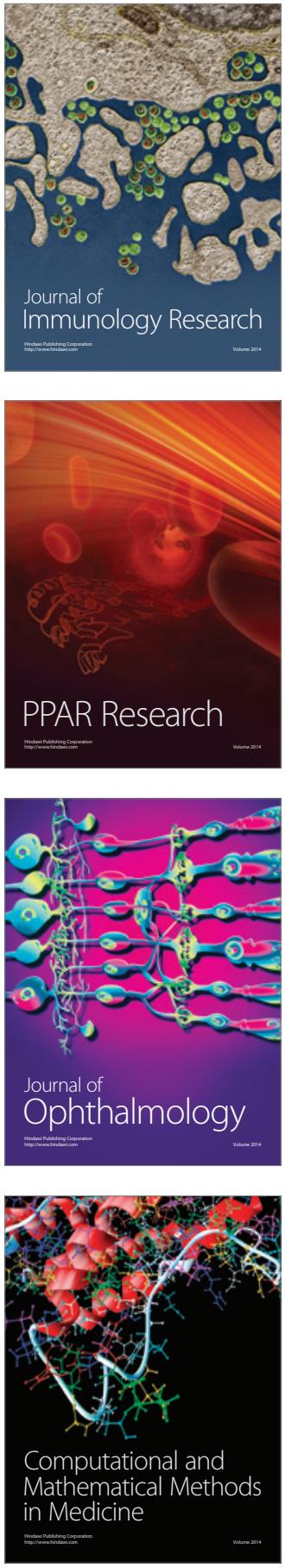

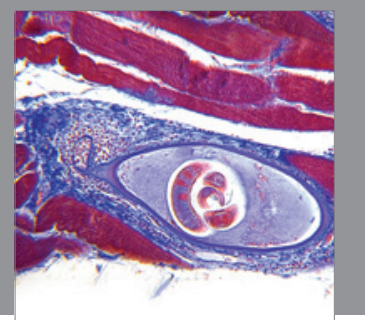

Gastroenterology

Research and Practice
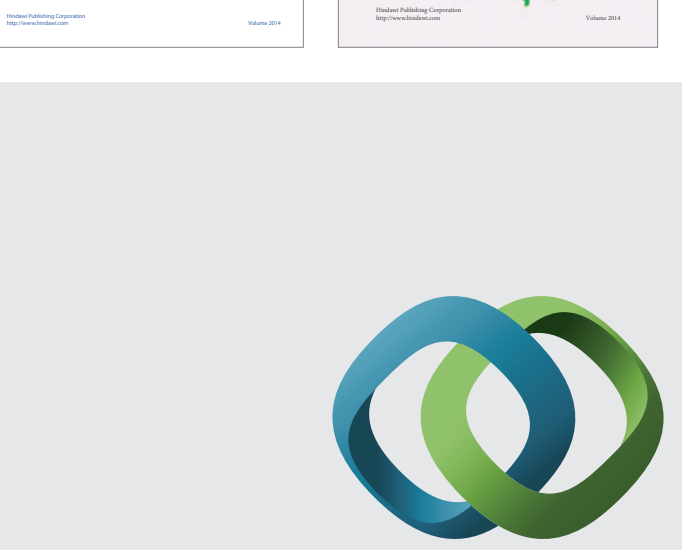

\section{Hindawi}

Submit your manuscripts at

http://www.hindawi.com
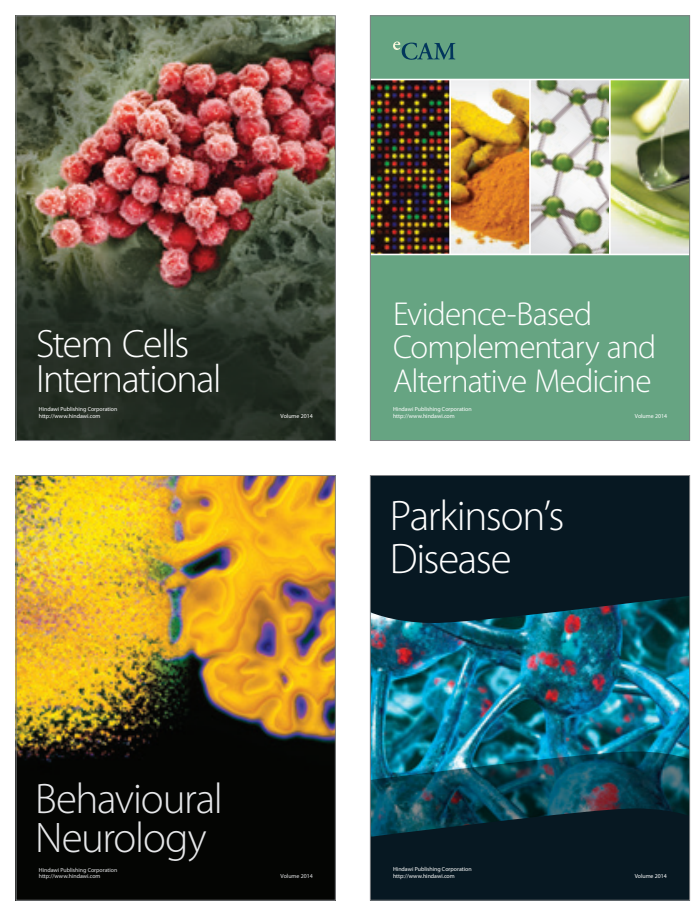

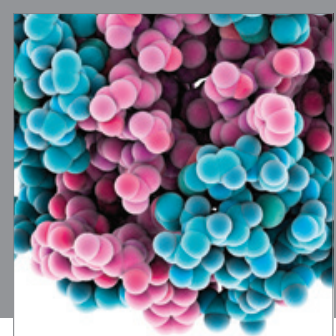

Journal of
Diabetes Research

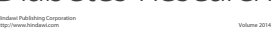

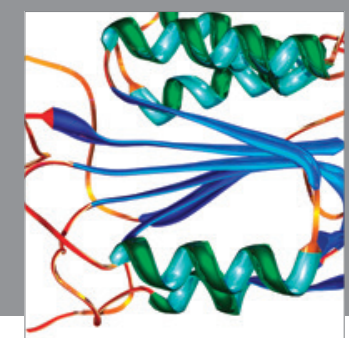

Disease Markers
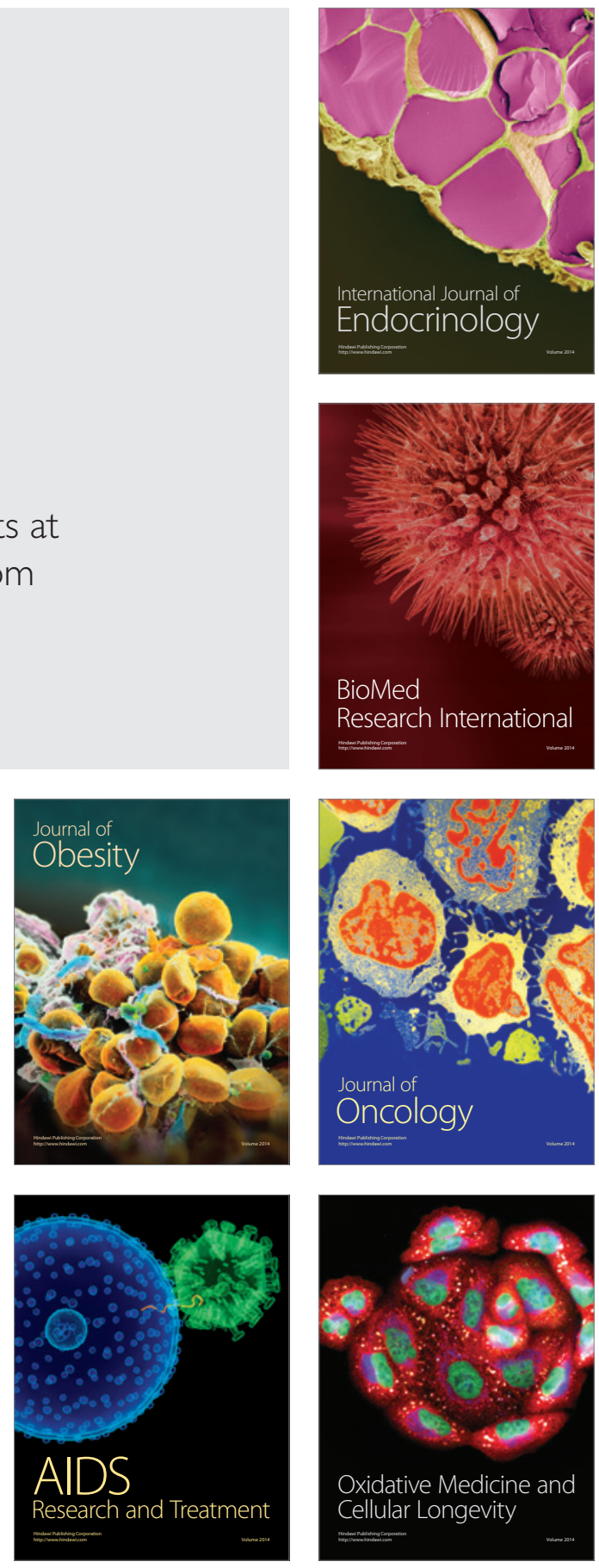